\title{
Autophagy in Alzheimer's disease pathogenesis: therapeutic potential and future perspectives
}

\author{
Zhigang Zhang ${ }^{1}$, You-Qiang Song ${ }^{2}$, and Jie $\mathrm{Tu}^{1}$ \\ ${ }^{1}$ Shenzhen Institutes of Advanced Technology, Chinese Academy of Sciences; \\ Shenzhen-Hong Kong Institute of Brain Science-Shenzhen Fundamental Research \\ Institutions \\ ${ }^{2}$ The University of Hong Kong
}

December 18, 2020

\begin{abstract}
Alzheimer's disease (AD) is a complex neurodegenerative disease in the elderly. It is the most common cause of dementia in human. $\mathrm{AD}$ is characterized by accumulation of abnormal protein aggregates including amyloid plaques (composed of betaamyloid $(\mathrm{A} \beta$ ) peptides) and neurofibrillary tangles (formed by hyper-phosphorylated tau protein). Besides, synaptic plasticity, neuroinflammation, calcium signaling etc. are found to be dysfunctional as well in AD patients. Autophagy is an evolutionarily conserved lysosome-dependent cellular event in eukaryotes. It is closely linked to the modulation of protein metabolism, through which damaged organelles and mis-folded proteins are degraded and then recycled to maintain protein homeostasis. Accumulating evidence has showed that impaired autophagy contributes to AD pathogenesis. In the present review, we highlight the role of autophagy, including bulk and selective autophagy, in regulating metabolic circuits in AD pathogenesis. We also discuss the potential and future perspectives of autophagy-inducing strategy in AD therapeutics.
\end{abstract}

\section{Hosted file}

Main document.pdf available at https://authorea.com/users/383547/articles/499427-autophagyin-alzheimer-s-disease-pathogenesis-therapeutic-potential-and-future-perspectives

\section{Hosted file}

Figure 1.pdf available at https://authorea.com/users/383547/articles/499427-autophagy-inalzheimer-s-disease-pathogenesis-therapeutic-potential-and-future-perspectives

\section{Hosted file}

Figure 2.pdf available at https://authorea.com/users/383547/articles/499427-autophagy-inalzheimer-s-disease-pathogenesis-therapeutic-potential-and-future-perspectives

\section{Hosted file}

Figure 3.pdf available at https://authorea.com/users/383547/articles/499427-autophagy-inalzheimer-s-disease-pathogenesis-therapeutic-potential-and-future-perspectives

\section{Hosted file}

Table 1.pdf available at https://authorea.com/users/383547/articles/499427-autophagy-inalzheimer-s-disease-pathogenesis-therapeutic-potential-and-future-perspectives 